\title{
FUNCTIONS OF THE JUVENILE COURT
}

\author{
By Hon. William H. DeLacy, \\ Judge of the Juvenile Court of the District of Columbia, Washington.
}

The establishment of juvenile courts is the most important development in the field of jurisprudence during the last decade. The first juvenile court was organized in Chicago, July I, I899. There, the juvenile court is presided over by one of the judges of the circuit court, a court of general, unlimited jurisdiction. The child is not regarded as a criminal. It is, rather, looked upon as needing the fostering care of the state by reason of its delinquency, which evidences the failure of its natural parents to train it to good citizenship. The court proceedings, as far as possible, are similar to proceedings in chancery. In Philadelphia, New York and elsewhere, the court is a criminal court. But, whether equitable or criminal, the attitude of the court toward the child is always the same-not that of a judge inflicting punishment, but the attitude of a father toward an erring child.

Dr. Hart did not tell you that the probation officers are used by the judge as investigators to obtain for him the sociological data necessary, that he may correct the wayward children. To do this, the judge must know of the environment of the children. Therefore, prior to the children's arraignment in court, probation officers are sent into their homes to learn the conditions there. Oftentimes this develops that well-grown children, of both sexes, have the same sleeping apartment, sometimes even the same bed. To provide the additional room required for decent living, we often find the earning capacity of the family ample if the money made were not dissipated in vicious expenditure. The very poor are encouraged to provide at least cheap screens, that the amenities may be somewhat possible.

Heredity, while an unknown quantity, is yet a force always to be reckoned with. Heredity is not a determining force, for God is good and I believe that He gives us all a fair chance.

By interviews with its parents, consideration of its personal history and its ancestry, careful consideration of its environment, and close observation of its physical condition, the court, in a sympathetic 
investigation of the child's shortcomings, seeks to find out and eradicate the cause of the child's violation of the law. While maintaining the respect and even the wholesome awe of the child for the law, the court proceedings are bereft of much of the formality observed in other tribunals.

It would be a dangerous thing to disregard the rules of evidence, and these rules are observed, of course, in the juvenile, or children's, court. It is arranged so that the child may come quite close to the judge, that the judge may both reassure and have a better opportunity to study him.

Juvenile court systems tend to diminish, in a very large degree, the work of grand juries and criminal courts. This alone saves hundreds of dollars of expense to the community. In addition, a large proportion of the children tried in juvenile courts are handled by the method of probation which obviates, to a very great degree, the necessity for their incarceration at the expense of the public in institutions. While on probation, these children are under the supervision and the custodial care of the court, but are suffered to remain at their homes, where the cost of their nurture and training naturally belongs. The actual saving in dollars and cents, by reducing the number committed to institutions, is no inconsiderable item, and frequently amounts to as much as $\$ 70,000$ per annum in cities of 300,000 . This saving is not all, for the earnings of these children while on probation add much to the wealth of their communities.

The work of the juvenile court is not only remedial, but preventive. The juvenile court is the most promising point at which to arrest the rising tide of crime. Its whole aim is to save the child from a life of crime and the conservation and preservation of the child to himself, to his parents and to the state. This work has the superlative value of the ounce of prevention.

Probation is character-building. That the probation system may be successful, the judge must take an active interest in its workings and be, in fact, though not in name, his own chief probation officer. No better social service is done to-day throughout the country than that rendered by probation officers.

Another great saving to the state is also made by the careful investigation of the cases of alleged dependents seeking admission into institutions maintained at public expense. 
The exposure and punishment of parental neglect is a feature that stops much violation of the law; for parental neglect and parental inefficiency are prolific causes of the wrongdoing of the children. When homes are found to be morally unfit to train children to good citizenship, I thank God that there are excellent institutions to receive them and to shelter them, presided over by such earnest and cultured and zealous souls as Mr. Nibecker, to whom we listened this afternoon.

The enforcement of the parental obligation to support the family is another preventive feature of the work of many juvenile courts. The family is the real unit in the state. If the children are fed in their homes they are less likely to beg or steal. In Washington, during the past three years, over $\$ 85,000$ was thus collected from delinquent husbands and fathers, and paid through the clerk of the court to wives for the benefit of these children, without any deduction for costs or otherwise. This result has been made possible by the co-operation of the police force, under whose supervisory care these men found guilty of non-support are released either on probation or by parole.

Finally, the juvenile court is the natural center in the community around which to group all the social efforts made to remedy defective home conditions, to safeguard the health and morals of the young, and to insure the children an atmosphere friendly to the development of the highest citizenship. 